\title{
A new species of the genus Stathmopoda (Lepidoptera: Stathmopodidae) closely related to the persimmon pest, S. masinissa, from Ryukyu Islands, Japan
}

\author{
Takeshi Terada • Yositaka Sakamaki • \\ Suguru Ohno
}

Received: 27 October 2010/Accepted: 30 March 2011/Published online: 24 May 2011

(c) The Author(s) 2011. This article is published with open access at Springerlink.com

\begin{abstract}
A new species of the genus Stathmopoda from the Ryukyu Islands, Japan, is described. The new species is associated with Diospyros maritima Blume and is very similar to $S$. masinissa Meyrick, which is a notorious pest of persimmon, D. kaki L., in Japan and Korea. The adult external features, wing venation, and male and female genitalia of both species are illustrated and compared in detail.
\end{abstract}

Keywords Taxonomy $\cdot$ Stathmopoda maritimicola $\mathrm{n}$. sp. · Diospyros

\section{Introduction}

We examined specimens of stathmopodid moths injurious to fruit of the persimmon, Diospyros kaki L., and a congeneric species, D. maritima Blume, from the Ryukyu Islands, and determined that the specimens consisted of two species belonging to the genus Stathmopoda. One was a new species, and the other was a notorious pest of persimmon, S. masinissa; they very similar and closely related. In this paper, we describe the new species and redescribe the pest species, with illustrations and remarks on their distinguishing characteristics, taxonomical status, and distribution.

T. Terada $\cdot$ Y. Sakamaki $(\bowtie)$

Entomological Laboratory, Graduate School of Agriculture,

Kagoshima University, 1-21-24 Korimoto,

Kagoshima 890-0065, Japan

e-mail: ysaka@agri.kagoshima-u.ac.jp

S. Ohno

Okinawa Prefectural Agricultural Research Center,

Itoman, Okinawa 901-0336, Japan

\section{Materials and methods}

Most specimens were collected in Kyushu and the Ryukyu Islands, Japan, in June 2001, January-June 2005, May-July 2009, and July-September 2010 and were deposited in the collection of the Entomological Laboratory, Kagoshima University (KGU), Japan. The other specimens were borrowed from the collection of the Entomological Laboratory, Osaka Prefecture University (OPU), Japan. Wing venation was observed after preparation. Detached wings were cleaned with a raccoon-fur brush in $40 \% \mathrm{EtOH}$ to remove scales and were stained with acid fuchsine solution. Male and female genitalia were dissected after maceration for $4-5 \mathrm{~h}$ in $10 \%$ aqueous potassium hydroxide $(\mathrm{KOH})$, heated with lactic acid in a drying oven $\left(60^{\circ} \mathrm{C}\right)$, and stained with mercurochrome solution. The terminology follows Kasy (1973), Yasuda (1988), and Koster and Sinev (2003).

\section{Results and discussion}

Taxonomy

Stathmopoda maritimicola Terada \& Sakamaki n. sp.

[Japanese name: Ryukyukakinohetamushiga]

Diagnosis (Fig. 1-4). This new species is very similar to S. masinissa but can be distinguished by the coloration of the head, thorax, and forewing. In the new species, the head is brownish black, the forewing has yellow markings, and the thorax has a pair of yellow markings subdorsally. In contrast, in S. masinissa, the head is ocher, the forewing has an ocher marking, and the thorax has a single ocher marking mesially. 

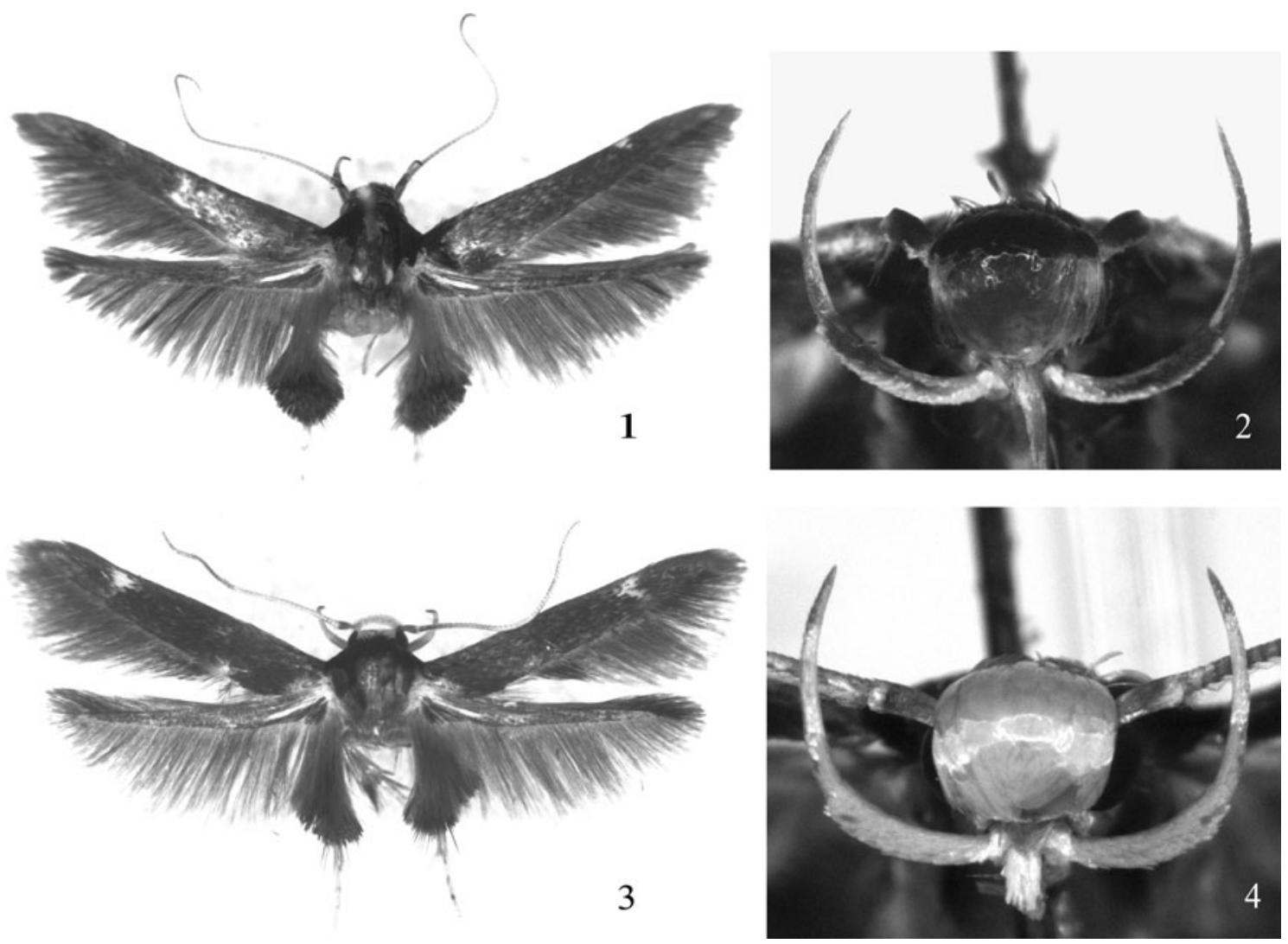

Figs. 1-4 Adult specimens and head in front view. Fig. 1 Holotype; Fig. 2 paratype, Stathmopoda maritimicola n. sp. $\widehat{\jmath} ;$ Figs. 3, 4 S. masinissa $\widehat{\jmath}$

Description. Wing expanse $11.6-18.4 \mathrm{~mm}$. Forewing length 5.3-8.4 mm. Labial palpus ocher, first and second segments blackish brown dorsally, third segment blackish brown ventrally. Scape blackish brown dorsally, ocher ventrally. Head brownish black, frons blackish brown to ocher (Fig. 2). Thorax brownish black, with a pair of yellow subdorsal markings near the caudal margin (Fig. 1). Legs ocher; forefemur and foretibia darkened to brownish black ventrally; midtibia covered with numerous brownish black hairs dorsally; hindtibia brownish black, verricule present dorsally. Abdomen blackish brown dorsally, pale ocher to ocher ventrally; spines of abdominal terga present on second to seventh segments in males, second to sixth segments in females, ocher; anal tuft, dark brown dorsally and ocher ventrally in males, entirely ocher in females.

Wing venation (Fig. 5). Forewing widest near base; 13 veined; discoidal cell long, occupying basal 7/10 of wing. Sc connected with costal margin of wing on basal $2 / 5$. $\mathrm{R}_{1}$ running from about distal $1 / 4$ of cell; $R_{2}$ from near upper angle of cell; $R_{3}, R_{4}$, and $R_{5}$, stalked. $M_{1}$ and $M_{2}$ parallel, but $\mathrm{M}_{3}$ approximate to $\mathrm{M}_{2}$ at base. $\mathrm{CuA}_{1}$ and $\mathrm{CuA}_{2}$ from about distal $1 / 10$ and $1 / 4$ of cell. $\mathrm{CuA}_{2}$ sometimes rudimentary near base. $1 \mathrm{~A}+2 \mathrm{~A}$ connected about basal $1 / 5$ of wing. Hindwing $5 / 6$ as long as forewing; nine veined; discoidal cell open. Rs running to near apex of costa. $\mathrm{M}_{2}$, $\mathrm{M}_{3}$, and $\mathrm{CuA}_{1}$ stalked, in common with $\mathrm{CuA}_{2} ; \mathrm{CuA}_{2}$ running to about $2 / 5$ of dorsum.

Wing markings (Fig. 1). Forewing brownish black; yellow marking present at about $3 / 4$ of costa, not reaching tornus, subtriangular, or sometimes absent in male, rectangular in female; cilia dark brown. Hindwing dark brown; cilia dark brown.

Male genitalia (Fig. 7-9). Uncus slender, tapering caudally, with apex pointed and downturned. Gnathos stout, longer than uncus, with apex slightly downcurved and acute in lateral view, round in dorsal view. Valva broad with rounded apex; costa angled caudally; cucullus rather small, 1.3 times as long as uncus, with numerous setae on inner surface; sacculus sclerotized, long, round at apex, with pointed apical process sticking out ventrally, 1/5 length of sacculus. Vinculum rather stout; saccus 1.2 times as long as uncus and rounded cephalically. Juxta subrectangular. Anellar lobes developed, subtriangular, weakly sclerotized, with setae on surface. Aedeagus six times as long as uncus, with apical patch of stimuli; a sclerotized structure present at near base, subrectangular; short to long cornuti arranged at cephalic $1 / 4$ of aedeagus in a group; caudal $1 / 2$ of aedeagus membranous, with rounded apex. 
Figs. 5 and 6 Wings: shape and venation. Fig. 5 Stathmopoda maritimicola $\mathrm{n}$. sp.; Fig. 6 S. masinissa
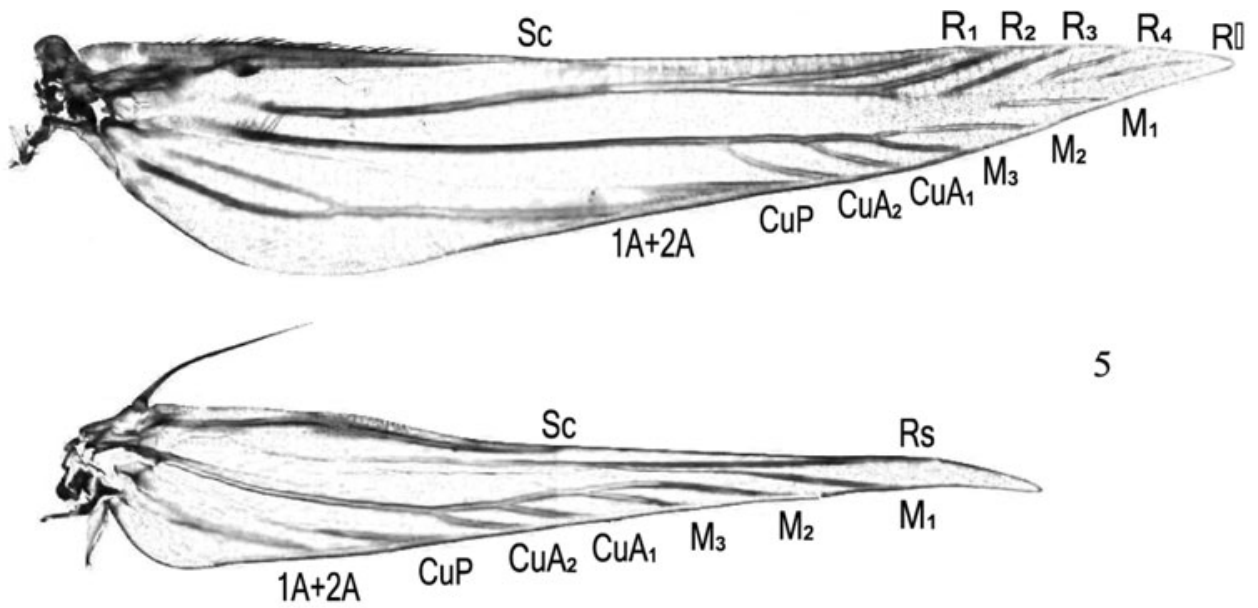

5

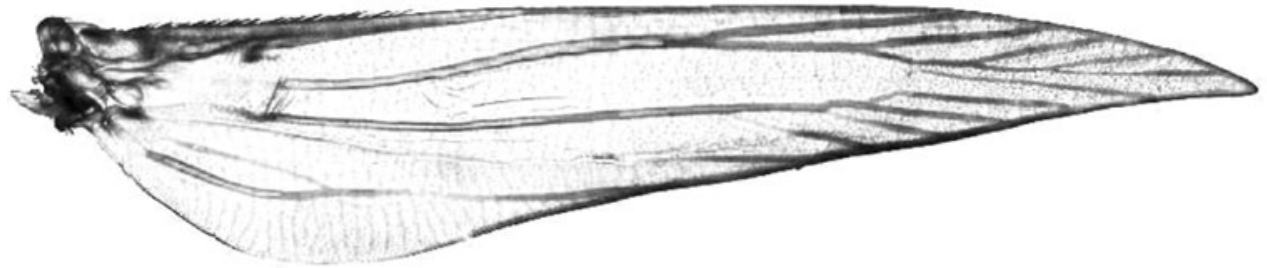

6

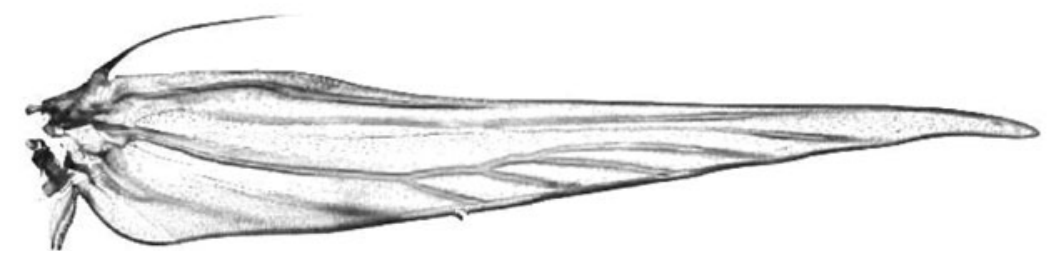

Female genitalia (Fig. 10-12). Seventh sternum with emarginate caudal margin. Papillae anales longer than wide, weakly sclerotized, with many short and long setae over entire surface; joint membrane between papillae anales and eighth abdominal segment slightly longer than papillae anales. Eighth abdominal segment sclerotized dorsally, triangular cephalically, with short and long setae arranged along caudal margin. Apophyses anteriores long; apophyses posteriores about 1.5 times as long as apophyses anteriores. Ostium bursae broad cup-shaped, emarginate in cephalic margin, with a pair of folds laterally and oval hollow in the middle; folds approaching each other toward the cephalic margin. Ductus bursae very short; cervix bursae very large, 3/4 of corpus bursae in diameter, assimilated with corpus bursae, with wrinkles. Corpus bursae with numerous microspines over surface; spines large at either end of corpus bursae and near signum. Signum lozenge, with streak of fold, situated at middle of corpus bursae. Ductus seminalis short, originating from cephalic side of corpus bursae.

Type material. Holotype $\hat{\jmath}$, Hirara-City, Miyako Island, Ryukyu Islands (Okinawa Prefecture), Japan, em.
25-26 January 2005, larva 19 December 2004, (S. Ohno leg.) (1 $\widehat{\jmath}$ Gen. sl. no. 10041), deposited in KGU. Paratypes, Japan: Ryukyu Islands: Okinawa-Pref.: 3ð 2ㅇ, Yonaguni Island., em. 18 January-5 February 2005, (S. Ohno leg.) (1乞ิ 1 ㅇ Gen. sl. no. 10024, Sta-10002); 1ðَ 2ㅇ, Miyako Island., Hirara-City, em. 25 January-15 February 2005, (S. Ohno leg.) (1ðَ Wing sl. no. 10020, 1 † Gen. sl. no. 10042); 2ㅇ, Kume Island., em. 15-26 February 2005 (S. Ohno leg.) (1ㅇ Gen. sl. no. 10025); 1今ै, Kume Island., 14-16 June 2005 (S. Ohno leg.) (pheromone trap); 2ิ, Irabu Island., em. 25-26 January 2005 (S. Ohno leg.) (2ð̋ Gen. sl. no. Sta-10001, 10039); 1へิ, Tarama Island., em. 23-30 April 2005 (S. Ohno leg.) (1ðَ Wing sl. no. 10018); 1옹 Ishigaki Island., Mt. Omoto, 31 March 2002, (T. Hirowatari et al. leg.); 19, Iriomote Island., Uehara, 26 March 2002 (N. H. Ahn et al. leg.).

Distribution. Japan: Ryukyu Islands. (Okinawa Prefecture).

Host plant. D. maritima Blume (Ebenaceae).

Biology. Scarcely known. Adults emerge in late winter, midspring, and early summer at least. Mature larvae bore into the fruit of the host plant. 
Figs. 7-9 Stathmopoda maritimicola n. sp., male genitalia. Fig. 7, Caudal view, aedeagus omitted (jx: juxta; al: anellar lobes); Fig. 8, lateral view, aedeagus omitted; Fig. 9, aedeagus (ap: apical patch of stimuli; ss: sclerotized structure)

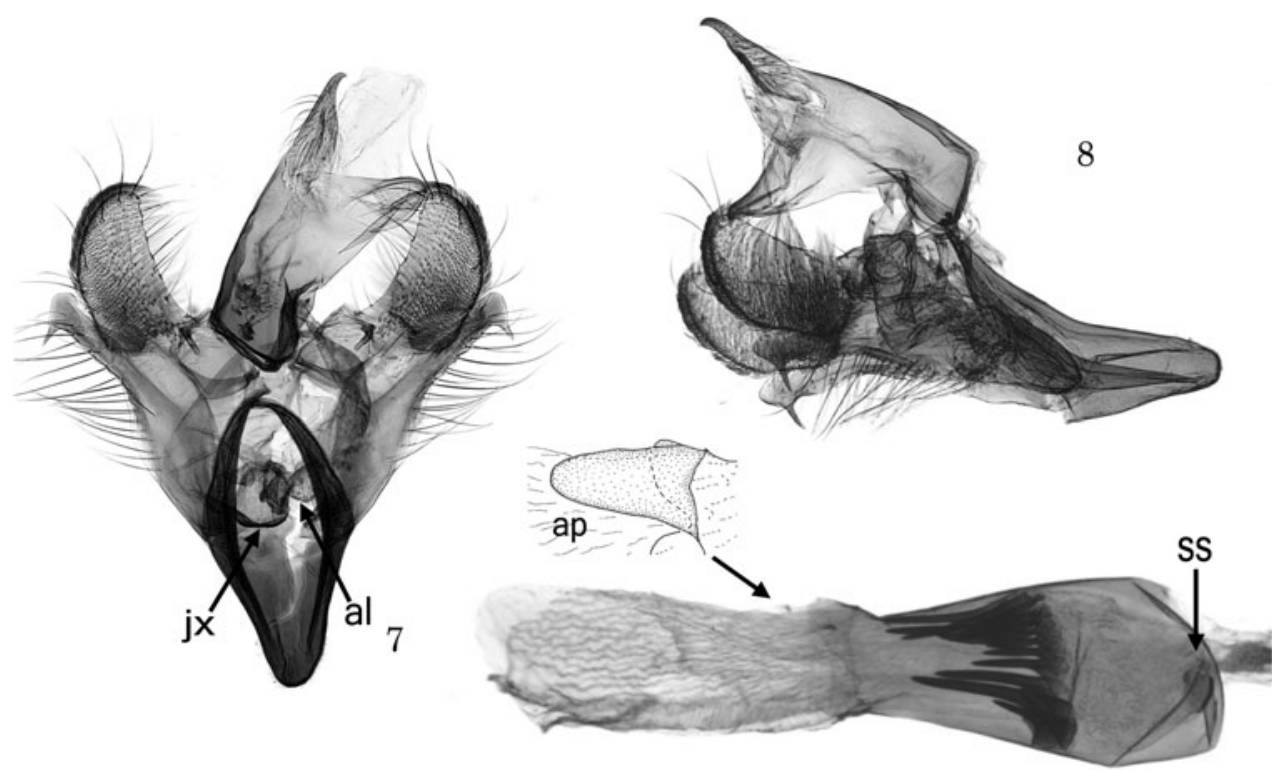

9

Figs. 10-12 Stathmopoda maritimicola $\mathrm{n}$. sp., female genitalia. Fig. 10, ventral view; Fig. 11, ostium cup; Fig. 12, signum
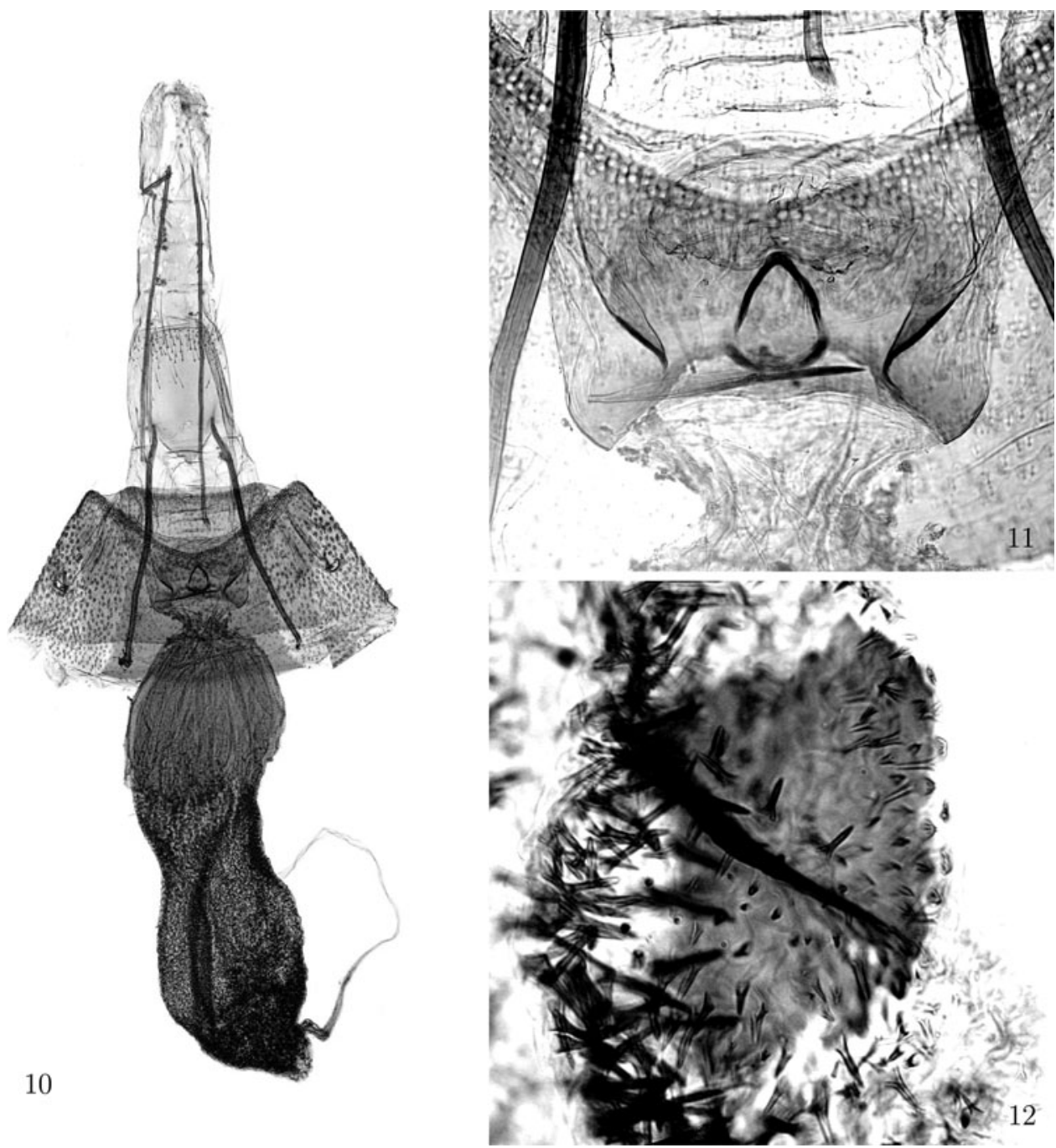
Figs. 13-15 Stathmopoda masinissa, male genitalia. Fig. 13, caudal view, aedeagus and anellar lobes omitted (jx: juxta); Fig. 14, lateral view, aedeagus omitted; Fig. 15, aedeagus (ap: apical patch of stimuli; al: anellar lobes; ss: sclerotized structure)

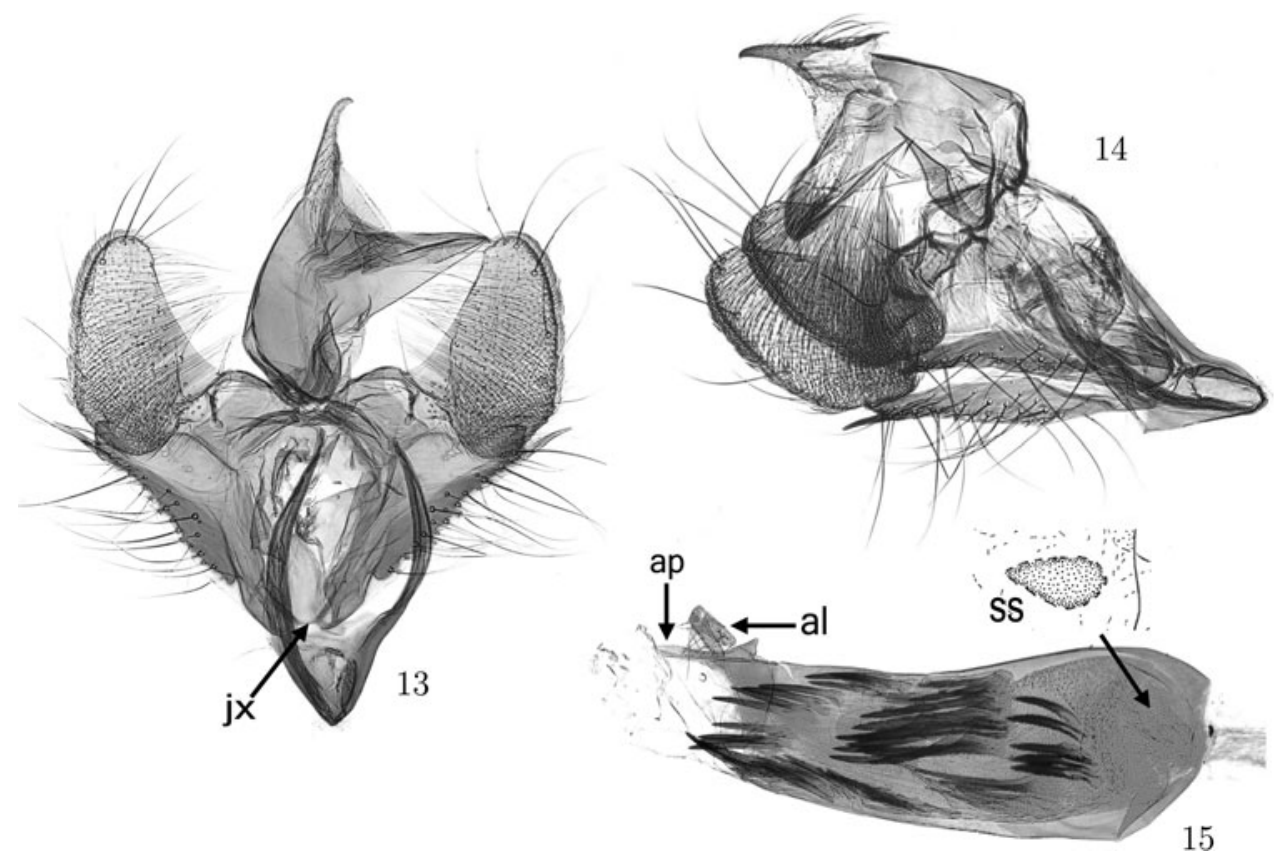

Remarks. As the new species is very similar to $S . m a-$ sinissa, it is difficult to distinguish them by the appearance of damaged samples. The sex pheromones of both species may include similar chemicals because the new species was captured in a pheromone trap for S. masinissa.

The two species are distinguished from other species in the genus Stathmopoda by the brownish black verricula on the hind tibia dorsally (Figs. 1, 3) and large cervix bursae (Figs. 10, 16). Because these characteristics are unique to the genus Stathmopoda, these species might be assigned a subgeneric status in the future.

The known distribution of $S$. maritimicola is extremely limited, although the host plant (D. maritima) is distributed widely in the south of Amami Islands, Taiwan, Southeast Asia, Micronesia, and Australia (Hatusima 1971). Surveys of these areas are needed to determine the actual distribution of the new species. Because the host plant is closely related to the edible Japanese persimmon, D. kaki, it is important for persimmon cultivation that the actual host range of the new species is known.

\section{Stathmopoda masinissa Meyrick}

[Japanese name: Kakinohetamushiga]

S. masinissa Meyrick 1906: 410. Type locality: Ceylon, Matale.

Kakivoria flavofasciata Nagano 1916: 136. Type locality: Japan, Gifu.

S. albidorsis Meyrick 1931: 75. Type locality: China, Kwanhsien.

Description. Wing expanse $12.2-18.2 \mathrm{~mm}$. Forewing length $5.9-8.1 \mathrm{~mm}$. Very similar to $S$. maritimicola $\mathrm{n}$. $\mathrm{sp}$. but differing in the following characteristics: Labial palpus ocher, near connection of first and second segments blackish brown dorsally. Scape brown to ocher dorsally, ocher ventrally. Head ocher (Fig. 4). Thorax brownish black, with ocherous mesial marking on dorsum near caudal margin of mesothorax (Fig. 3).

Wing venation (Fig. 6). Forewing $\mathrm{M}_{1}, \mathrm{M}_{2}$, and $\mathrm{M}_{3}$ parallel to each other. $\mathrm{CuA}_{1}$ and $\mathrm{CuA}_{2}$ rudimentary near base.

Wing markings (Fig. 3). Forewing with ocher marking at about $3 / 4$ of costa.

Male genitalia (Figs. 13-15). Costa of valva rounded, convex caudally; cucullus 1.8 times as long as uncus; sacculus sclerotized, with long setae ventrally; a short, straight process sticking out caudally from apex of sacculus, 1/5 length of sacculus. Vinculum rather elongate; saccus as long as uncus. Juxta tongue-shaped. Anellar lobes developed, subrectangular, weakly sclerotized, with setae on surface. Aedeagus five times as long as uncus, stout, slightly tapering toward apex, with apical patch of stimuli; a sclerotized structure present near base, oval; numerous spiniform cornuti forming groups, with middle group longer than others.

Female genitalia (Figs. 16-18). Seventh sternum with smooth caudal margin. Ostium bursae broad, quadrangular, parallel sided, with a pair of folds sublaterally; folds running parallel to each other. Ductus bursae very short and broad, wrinkled; cervix bursae large and round, clearly constrictive cephalically. Corpus bursae large, circular. Signum very large, sublozenge sclerotized plate, with vertical ridge on strong fold, situated at about middle of corpus bursae. Ductus seminalis long. 
Figs. 16-18 Stathmopoda masinissa, female genitalia. Fig. 16, ventral view; Fig. 17, ostium cup; Fig. 18, signum

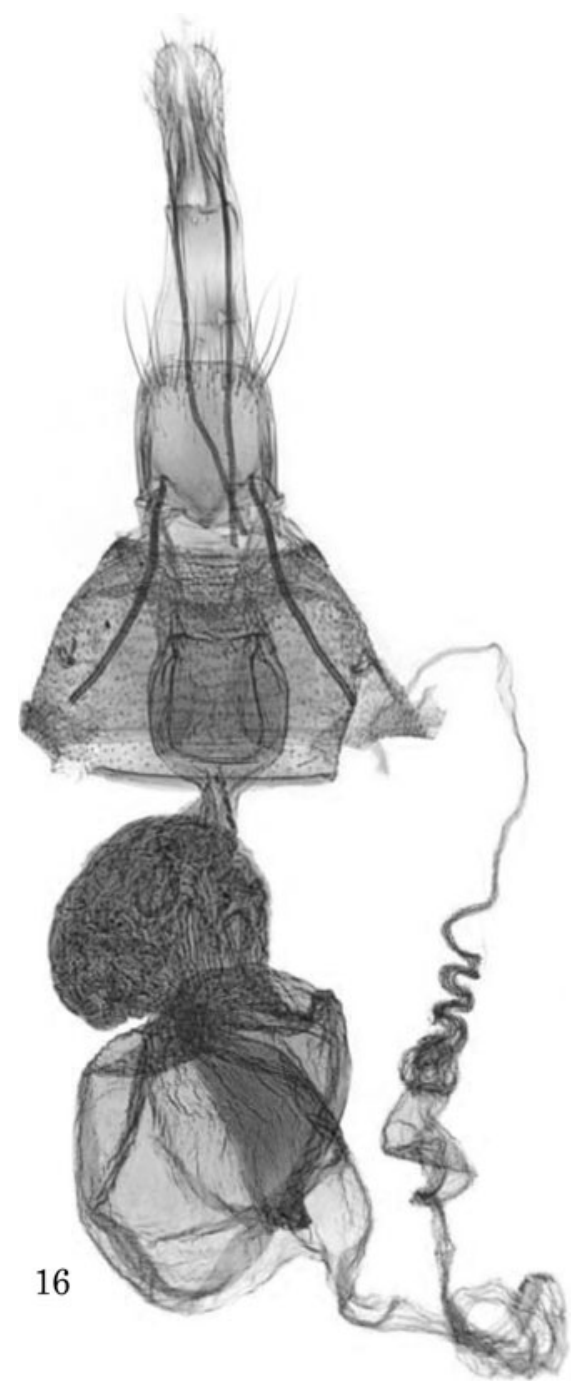

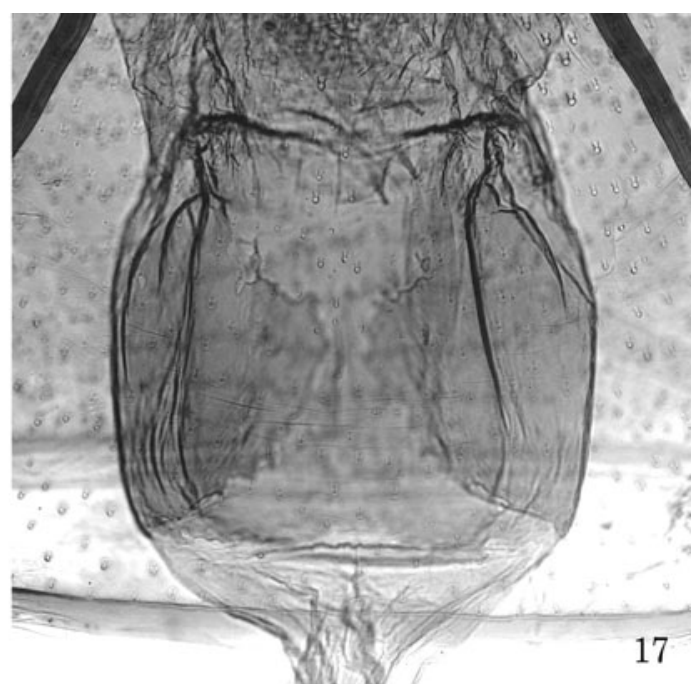

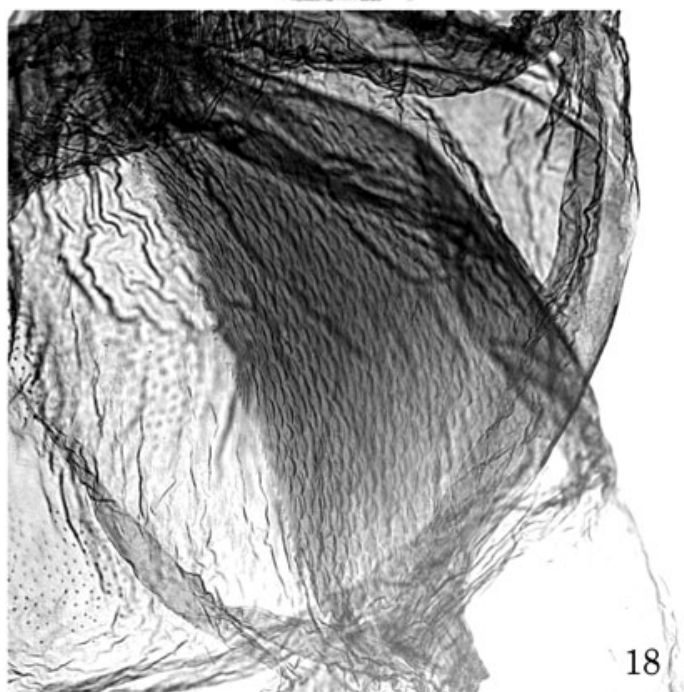

Specimens examined. Japan: Honshu: 1ठ, Gojou Ata, Nara Prefecture, 30 June 2000 (Y. Miyamoto leg.); 10, Mt. Kasagata, Hyogo Pref., em. 12 August 1968 (S. Moriuti leg.); Osaka Pref.: 1ㅇ, Mt. Inunaki, Kumatori Town, 5 June 2006 (B. W. Lee leg.); 1ㅇ, Tondabayashi, 30 July 1992, (S. Moriuti leg.); 10ิ, Yamate Town, 8 June 1978, (S. Moriuti leg.). Kyushu: Kagoshima Pref.: $3 \hat{\jmath}$ 3우, Kiiresesekushi, Kagoshima City, em. 27 August-5 Sep-

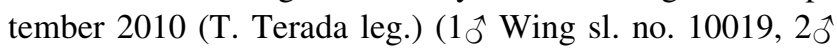
1 ㅇ Gen. sl. no. 10021, 10037, 10038); 1今̄, Toso, Kagoshima City, 22 July 2010 (T. Terada leg.) (Wing sl. no. 10017); 1, Uchizume, Sata Town, 9 June 2001 (K. Tsuda leg.); 1ㅇ, Seibu-rindo, Yakushima Town, 18 July 2009, (K. Nakamine leg.); 2 $\odot$, Hatsuno-rindo, Amami City, 13 May 2009, (K. Tsuda leg.) (1우 Gen. sl. no. 10022). Thailand: 19, Kao Yai, Nakorn Nayok, 26 August 1981, (Kuroko et al. leg.).

Distribution. Japan: Honshu, Shikoku, and Kyushu (Sasaki 1905). Taiwan, Sri Lanka, central China (Moriuti
1982), eastern China (Sinev 1999), Korea (Bae 1997), and Thailand (Moriuti and Yasuda 1982).

Host plants. D. kaki L. and D. lotus L. (Xu et al. 1996) (Ebenaceae).

Biology. S. masinissa is bivoltine and overwinters as the mature larva or the prepupa in Japan. Adults of the overwintering generation emerge in late spring to early summer. Eggs are deposited on the shoot of the host plant. Early larvae are found mining the shoots. Mid- to mature larvae feed near the joint of the calyx and fruit and mine the fruit. First-generation pupates in a cocoon made inside the fruit, behind the calyx or gap of cortex. Adults emerge in midsummer. Larvae of the overwintering generation are found in late summer to midautumn. They make the cocoon at the gap of the cortex and pupate in midspring of the next year.

Remarks. S. masinissa is a pest of persimmon (D. kaki). This species is distributed in East, Southeast, and South Asia, but the records are fragmented and insufficient. 
Acknowledgments Numerous individuals and institutions helped in this study. We greatly thank Dr. T. Hirowatari (OPU) and Dr. K. Tsuda (KGU) for use of their valuable collections on which this study is based. We also thank Dr. Y. Kunimoto (Nara Agricultural Experiment Station), the famers in Gojou, Nara, for providing facilities for our field work, Dr. H. Naka (Tottori University) for supplying a pheromone lure for $S$. masinissa, and Mr. T. Tanaka (KGU) for cooperating with our field work. Special thanks are due to the students of the Entomological Laboratory, KGU, for their kind guidance and constant encouragement.

Open Access This article is distributed under the terms of the Creative Commons Attribution Noncommercial License which permits any noncommercial use, distribution, and reproduction in any medium, provided the original author(s) and source are credited.

\section{References}

Bae SD (1997) Comparison in damaged aspect of wild persimmon fruit by second-generation larva of persimmon fruit moth, Stathmopoda masinissa Meyrick. RDA J Crop Prot 39(2):57-60 in Korean with English summary

Hatusima S (1971) Ebenaceae. In: Flora of the Ryukyus. Okinawa. Seibutsu-kyoiku Kenkyukai, Naha, pp 473-475

Kasy F (1973) Beitrag zur kenntnis der familie Stathmopodidae Meyrick 1913 (Lepidoptera, Gelechioidea). Tijidschr Entomol 116(13):227-299
Koster SJC and Sinev SY (2003) Family Stathmopodidae. In: Huemer $\mathrm{P}$ et al (eds) Microlepidoptera of Europe 5. Apollo Books, Stenstrup, pp 59-67, 216-217, 254-256, 320-323

Meyrick E (1906) Descriptions of Indian micro-Lepidoptera, II. J Bombay Nat Hist Soc 17:403-417

Meyrick E (1931) Stathmopoda albidorsis. In: Caradja A (eds) Second contribution to our knowledge about the Pyralidae and Microlepidoptera of Kwanhsien. Bull Sect Sci Acad Roum. 14:59-75

Moriuti S (1982) Stathmopodidae. In: H. Inoue et al (eds) Moths of Japan. Kodansha, Tokyo, 1: pp 256-258, 2: pp 207-208, pls. 10, 12, 227, 241, 245-256 (in Japanese)

Moriuti S, Yasuda K (1982) Stathmopoda masinissa Meyrick and Eretmocera impactella (Walker) (Lepidoptera: Stathmopodidae). New to fauna of Thailand. Appl Entomol Zool 18(3):431-432

Nagano K (1916) On a new micropterous moth from Japan. Konch Sek 20:136-140

Sasaki T (1905) Fruit tree pest. Seibido, Tokyo, pp 200-203 in Japanese

Sinev SYu (1999) Family Stathmopodidae. In: Ler PA (ed) Key to the insects of Russian Far East. 5 (2). Vladivostok, Dal'nauka, pp 28-42 in Russian

Xu S, Yang XD, Liu S, Wang H, Feng CG (1996) Study on the technology of controlling persimmon fruit worm (Kakivoria flavofasciata Nagano). J Agric Univ Hebei 19(1):68-72 in Chinese

Yasuda K (1988) Two new species of the genus Hieromantis (Lepidoptera, Stathmopodidae) from Japan. Kontyû 56(3):491497 